\title{
Validação no Brasil de protocolos de auto-avaliação do impacto de uma disfonia******
}

\author{
Validation in Brazil of self-assessment protocols for dysphonia \\ impact
}

\author{
Mara Behlau* \\ Gisele Oliveira** \\ Luciana de Moraes Alves dos Santos*** \\ Adriana Ricarte****
}

*Fonoaudióloga. Doutora em Distúrbios da Comunicação Humana pela Universidade Federal de São Paulo - Escola Paulista de Medicina (Unifesp - EPM). Docente Permanente do Curso de Pós-Graduação em Distúrbios da Comunicação Humana na Unifesp - EPM. Endereço para Correspondência: Rua Machado Bittercourt, 361 - São Paulo - SP - CEP 04044001 (mbehlau@uol.com.br).

**Fonoaudióloga. Doutoranda em Distúrbios da Comunicação Humana pela Unifesp - EPM. Professora do Curso de Especialização em Voz do Centro de Estudos da Voz (CEV).

***Fonoaudióloga. Especialista em Voz pelo Conselho Federal de Fonoaudiologia com Curso no CEV. Pesquisadora Associada ao CEV.

****Fonoaudióloga. Mestranda em Distúrbios da Comunicação Humana pela Unifesp - EPM. Pesquisadora Associada ao CEV.

******Trabalho Realizado no CEV.

Artigo Original de Pesquisa

Artigo Submetido a Avaliação por Pares

Conflito de Interesse: não

Recebido em 10.03.2008

Revisado em 09.05.2008; 12.06.2008;

07.08.2008; 06.11.2009.

Aceito para Publicação em 06.11.2009.

\begin{abstract}
Background: a patient's self-assessment of his/hers vocal problem and the analysis of the results of a treatment are means used to verify the effectiveness of an intervention and to develop directive procedures for clinical health practice. Psychometric instruments are the most common tools used to perform this task. Validation of self-assessment instruments may be carried out in several ways; however there should be clear and structured criteria involved in this process. Aim: to present the validation process of three voice self-assessment instruments for the Brazilian Portuguese language: Voice-Related Quality of Life V-RQOL, Voice Handicap Index - VHI and, Voice Activity and Participation Profile - VAPP. These instruments received respectively the following names: Qualidade de Vida em Voz - QVV, Índice de Desvantagem Vocal - IDV and Perfil de Participação e Atividades Vocais - PPAV, emphasizing their specificities and the necessary adaptations for their use in Brazil. Method: The three questionnaires were validated following the guidelines suggested by the Scientific Advisory Committee of Medical Outcomes Trust - SAC. Results: the psychometric measures of validity, reliability, reproducibility and sensitiveness were statistically demonstrated for each instrument. Conclusions: the Brazilian versions of the V-RQOL, VHI and VAPP demonstrated to be valid, reliable and sensitive instruments that specifically assess patients who present voice problems. These instruments can be used in the assessment of the life quality related to voice, as well as for the analysis of treatment outcomes.
\end{abstract}

Key Words: Validation Studies; Voice; Quality of Life.

\section{Resumo}

Tema: a auto-avaliação de um indivíduo sobre seu problema de voz e a análise do resultado de um tratamento são meios utilizados para verificar a efetividade de uma intervenção e desenvolver procedimentos diretivos para a prática clínica na área da saúde. Instrumentos psicométricos são as ferramentas mais comuns para essa tarefa. A validação de instrumentos de auto-avaliação pode ser realizada de diversas formas, com critérios claros e estruturados. Objetivo: apresentar o processo de validação para o Português Brasileiro de três protocolos de auto-avaliação para voz: Voice-Related Quality of Life - V-RQOL, Voice Handicap Index - VHI e Voice Activity and Participation Profile - VAPP, que receberam os seguintes nomes respectivamente: Qualidade de Vida em Voz - QVV, Índice de Desvantagem Vocal - IDV e Perfil de Participação e Atividades Vocais - PPAV, ressaltando as particularidades desses intrumentos e as adaptações necessárias para seu uso no Brasil. Métodos: os três protocolos foram validados de acordo com os atributos sugeridos pelo Scientific Advisory Committee of Medical Outcomes Trust - SAC. Resultados: os três protocolos tiveram as medidas psicométricas de validade, confiabilidade, reprodutibilidade e sensibilidade estatisticamente demonstradas, apresentando particularidades inerentes ao foco do instrumento. Conclusão: as versões brasileiras dos protocolos QVV, IDV e PPAV mostraram ser instrumentos específicos para avaliar pacientes que apresentam problemas de voz, com validade, confiabilidade e sensibilidade comprovadas. Tais instrumentos podem ser propostos para avaliação da qualidade de vida relacionada à voz, bem como para análise de resultado de tratamentos.

Palavras-Chave: Estudos de Validação; Voz; Qualidade de Vida.

Referenciar este material como:

$\Omega$ Behlau M, Oliveira G, Santos LMA, Ricarte A. Validation in Brazil of self-assessment protocols for dysphonia impact (original title: Validação no Brasil de protocolos $\sum 3$ de auto-avaliação do impacto de uma disfonia). Pró-Fono Revista de Atualização Científica. 2009 out-dez;21(4):326-32. 


\section{Introduction}

World Health Organization (WHO) widened the concept of health so that it includes quality of life in its definition of complete physical, mental, and social well being. 1 Therefore, health and treatment outcome examination must incorporate not only the indicators of severity and frequency of illness, but also an estimate of well being, which can be measured by evaluating the individual's quality of life. WHO defines "quality of life" as the individual's perception of their position in life in the context of the culture and value systems in which they live and in relation to their goals, expectations, standards, and concerns 2,3 that may be affected in many different ways according to the individual's physical health, psychological state, level of independence, social relations, and personal beliefs, as well as environmentally related characteristics.

Assessment of quality of life is basically done by means of questionnaires, many of which are developed in English. In case these instruments are used in other languages, they must be translated and adapted and their measuring properties must be submitted to psichometric tests. 4,5 The instrument must be able to evaluate specific populations, for instance patients with a particular disorder, such as dysphonia6 (represents a difficulty that hinders natural voice production) and also focus on the assessment of special population, such as pediatric disfonia.7

A simple translation of a questionnaire is below the necessary for its administration. There are different ways of validating these instruments and one of them that should be highlighted is the guidelines set by the Scientific Advisory Committee of the Medical Outcomes Trust-SAC8 that suggests 8 attributes to be followed. The first attribute is related to the rationale for and description of the concept and the populations that a measure is intended to assess and the relationship between these concepts. The second is the reliability that is the degree to which an instrument is free from random error. The third is validity and it relates to the degree to which the instrument measures what it purports to measure. The fourth is the responsiveness that is the ability that the instrument has to detect change overtime. The fifth is the interpretability that relates to the degree to which one can assign easily understood meaning to an instrument's quantitative scores. The sixth is the burden that is the time, effort, and other demands related to the administration of the instrument. The seventh are the alternatives modes of administration and finally the eightieth is the cultural and language adaptations or translations that involve assessment of conceptual and linguistic equivalence as well as evaluation of measurement properties.

The purpose of this study is to present the validation process of three self-assessment questionnaires into Brazilian Portuguese emphasizing their particularities and necessary adaptation to be used in Brasil. These instruments assess the impact of a voice problem and were originally developed in English. The validation process was based on the guidelines suggested by the SAC that were described above.

\section{Methods}

The importance of the self-assessment of individuals with dysphonia built up efforts to validate this kind of instruments in Brazil. Up to now, 3 questionnaires were validated: Voice-Related Quality of Life9, translated as QVV - Qualidade de Vida em Voz10,11, Voice Activity and Participation Profile 12, translated as PPAV - Perfil de Participação e Atividades Vocais13 and Voice Handicap Index14, translated as IDV- Índice de Desvantagem Vocal15. Each study was approved by the Ethical Committee of the Instituition they were validated under (QVV - UNIFESP \# 1151/ 04;PPAV-CEV\#4313/05; IDV-CEV\#2313/05) and all the participants signed the Consent Term.

The validation process was similar for the three instruments and can be summarized as follows: questionnaires were translated by two bilingual speech-language pathologists and English teachers, and the back-translation was done by an English teacher who had not participated in the previous stage. The three translators were informed about the objective and procedure of the research. Acommittee of five voice specialists revised the final protocol. To evaluate cultural and linguistic equivalency, the option "not applicable" was introduced to each item of the questionnaire, which was then administered to patients that did not take part in the final administration. None of the questions of the three tools was shown to be invalid.

Statistical Package for Social Sciences, version 10.0, was used to perform all statistical analysis. The level of significance adopted was 5\% (0.050). Validity was determined by comparing the questionnaires scores to the self-rating of voice quality with the Kruskal-Wallis test. To determine internal consistency, Cronbach's alpha correlation coefficient was generated and Wilcoxon matchedpairs signed-ranks test was performed to determine reproducibility. To determine test-retest reproducibility voice patients were administered the questionnaires a second time before treatment. A 
typical and effective retest interval is usually between 2 and 14 days. This period should be short enough so that not many changes have occurred, but long enough that patients would not remember their answers. Finally, responsiveness was evaluated by comparing pre-and posttreatment voice-quality ratings and the questionnaires scores.

Brazilian individuals, both sexes, volunteered to participate in the study. They had variable schooling and social-cultural levels and were distributed into two groups: with and without dysphonia. The participants with voice problem sought for help at university settings, with diagnosis performed by Otolaringologists and Speech-language Pathologists, and were free from treatment. The other group of participants was composed of vocally health individuals, with no history of past or present voice problem and also sought for help at university settings due to either dermatological or ophthalmological complaints.

For the present study, the steps of validation were compared among the three questionnaires with a highlight of their particularities and an analysis of their advantages and disadvantages.

\section{Results}

Results are presented in Tables 1 to 3 .

TABLE 1. Questionnaire characteristics.

\begin{tabular}{|l|l|l|l|}
\hline & QVV & PPAV & IDV \\
\hline Administration Time & Short & Moderate & Moderate \\
\hline Items subjects & Not repetitive & Not repetitive & Some degree of repetition \\
\hline Type of analysis & $\begin{array}{l}\text { Physical, Social-emotional and } \\
\text { Total Scores }\end{array}$ & $\begin{array}{l}\text { self-perceived severity of voice problem, effect } \\
\text { on job, effect on daily communication, effect on } \\
\text { social communicationand effect on emotions }\end{array}$ & $\begin{array}{l}\text { Organic, Functioning and } \\
\text { emotional Scores }\end{array}$ \\
\hline Aditional Scores & Does not have & $\begin{array}{l}\text { Two other: activity limitation and participation } \\
\text { restriction }\end{array}$ & Does not have \\
\hline $\begin{array}{l}\text { Comprehension of } \\
\text { numerical results }\end{array}$ & On a 100basis - easy & On a 280 basis - it requires transposition & $\begin{array}{l}\text { On a 120 basis - it requires } \\
\text { transposition }\end{array}$ \\
\hline $\begin{array}{l}\text { Interpretability of } \\
\text { qualitative results into } \\
\text { quantitative }\end{array}$ & $\begin{array}{l}\text { It does not provide an easy } \\
\text { interpretation }\end{array}$ & $\begin{array}{l}\text { It hás easy interpretation and allows treatment to } \\
\text { be focused on daily and social life, job and } \\
\text { emotions }\end{array}$ & $\begin{array}{l}\text { It does not provide an easy } \\
\text { interpretation }\end{array}$ \\
\hline Especific population & $\begin{array}{l}\text { Only one question is directed to } \\
\text { job aspects }\end{array}$ & It favors individuals that work & $\begin{array}{l}\text { It does not favor any } \\
\text { specific population }\end{array}$ \\
\hline $\begin{array}{l}\text { Dificulty to adapt to the } \\
\text { Brazilian Portuguese }\end{array}$ & $\begin{array}{l}\text { No dificulty in the items, but the } \\
\text { antroductory instruction for } \\
\text { answering the protocol was }\end{array}$ & None, two versions very similar & $\begin{array}{l}\text { Dificult to translate the } \\
\text { items due to the similarity } \\
\text { among some sentences }\end{array}$ \\
\hline
\end{tabular}

TABLE 2. Validity and Alpha Coefficient for each of the questionnaires.

\begin{tabular}{|c|c|c|c|}
\hline $\begin{array}{l}\text { Questionnaires/D } \\
\text { omains }\end{array}$ & Validity (p) & Alpha coefficient & Coefficient (p) \\
\hline \multicolumn{4}{|l|}{ QVV } \\
\hline Physical & 0,007 & 0,962 & $<0,001$ \\
\hline Social-emotional & 0,030 & 0,964 & $<0,001$ \\
\hline Total & 0,008 & 0,969 & $<0,001$ \\
\hline \multicolumn{4}{|l|}{ PPAV } \\
\hline Job & 0,026 & 0,896 & $<0,001$ \\
\hline Daily Communication & 0,005 & 0,920 & $<0,001$ \\
\hline Social Communication & 0,017 & 0,803 & $<0,001$ \\
\hline Emotion & $<0,001$ & 0,908 & $<0,001$ \\
\hline Total & $<0,001$ & 0,754 & $<0,001$ \\
\hline \multicolumn{4}{|l|}{ IDV } \\
\hline Emotional & $<0,001$ & 0,937 & $<0,001$ \\
\hline Functioning & $<0,001$ & 0,893 & $<0,001$ \\
\hline Organic & $<0,001$ & 0,750 & $<0,001$ \\
\hline Total & $<0,001$ & 0,888 & $<0,001$ \\
\hline
\end{tabular}


TABLE 3. Reproducibility and responsiveness for each questionnaire.

\begin{tabular}{|c|c|c|c|c|c|c|}
\hline \multirow{3}{*}{ Questionnaires/ Domains } & \multicolumn{6}{|c|}{ Scores } \\
\hline & \multicolumn{3}{|c|}{ Reproducibility } & \multicolumn{3}{|c|}{ Responsiveness } \\
\hline & Mean & SD & (p) & Mean & SD & (p) \\
\hline \multicolumn{7}{|l|}{ QVV } \\
\hline \multicolumn{7}{|l|}{ Physical } \\
\hline Time 1 & 62,7 & 22,8 & \multirow{2}{*}{0,700} & 66,5 & 19,4 & \multirow{2}{*}{0,026} \\
\hline Time 2 & 63,0 & 23,6 & & 77,2 & 18,5 & \\
\hline \multicolumn{7}{|l|}{ Social-emotional } \\
\hline Time 1 & 70,6 & 26,2 & \multirow{2}{*}{0,070} & 73,7 & 26,6 & \multirow{2}{*}{0,006} \\
\hline Time 2 & 72,3 & 26,5 & & 89,2 & 14,0 & \\
\hline \multicolumn{7}{|l|}{ Total } \\
\hline Time 1 & 65,9 & 22,0 & \multirow{2}{*}{0,108} & 69,5 & 20,4 & \multirow{2}{*}{0,008} \\
\hline Time 2 & 66,9 & 22,5 & & 81,9 & 14,2 & \\
\hline \multicolumn{7}{|l|}{ PPAV } \\
\hline \multicolumn{7}{|l|}{ Job } \\
\hline Time 1 & 13,4 & 11,8 & \multirow{2}{*}{0,246} & 12,4 & 12,5 & \multirow{2}{*}{0,116} \\
\hline Time 2 & 13,5 & 11,6 & & 1,9 & 0,9 & \\
\hline \multicolumn{7}{|l|}{ Daily Communication } \\
\hline Time 1 & 43,1 & 29,7 & \multirow{2}{*}{0,345} & 42,6 & 12,5 & \multirow{2}{*}{0,046} \\
\hline Time 2 & 43,4 & 29,3 & & 6,8 & 2,2 & \\
\hline \multicolumn{7}{|l|}{ Social Communication } \\
\hline Time 1 & 12,7 & 10,8 & \multirow{2}{*}{0,618} & 7,1 & 6,9 & \multirow{2}{*}{$0,24 \mathrm{c}$} \\
\hline Time 2 & 12,6 & 11,1 & & 2,4 & 1,1 & \\
\hline \multicolumn{7}{|l|}{ Emotion } \\
\hline Time 1 & 24,2 & 17,7 & 0,367 & 15,7 & 16,3 & 0.046 \\
\hline Time 2 & 23,1 & 18,1 & & 1,6 & 0,8 & \\
\hline Total & & & & & & \\
\hline Time 1 & 98,8 & 60,6 & 0,545 & 83,0 & 63,3 & 0.046 \\
\hline Time 2 & 98,0 & 59,1 & & 13,0 & 4,6 & \\
\hline IDV & & & & & & \\
\hline Emotional & & & & & & \\
\hline Time 1 & 13,92 & 6,71 & 0,700 & 12,8 & 5,8 & 0.005 \\
\hline Time 2 & 14,92 & 6,85 & & 2,6 & 2,4 & \\
\hline Functioning & & & & & & \\
\hline Time 1 & 11,98 & 5,44 & 0,700 & 10,8 & 5 & 0.005 \\
\hline Time 2 & 13,25 & 5,69 & & 4,2 & 1,6 & \\
\hline Organic & & & & & & \\
\hline Time 1 & 22,23 & 6,24 & 0,700 & 22,3 & 4,6 & 0,005 \\
\hline Time 2 & 24,06 & 7,37 & & 3,7 & 3,4 & \\
\hline Total & & & & & & \\
\hline Time 1 & 48,13 & 15,31 & 0.700 & 45,9 & 12,4 & 0,005 \\
\hline Time 2 & 52,37 & 16,6 & & 10,5 & 6,2 & \\
\hline
\end{tabular}

Time 1 for reproducibility is the Test and for respon siveness id Pre-treatment

Time 2 for reproducibility is the Retest and for responsiveness id Post-treatment 


\section{Discussion}

The main characteristics of the questionnaires allow a quick comparison of their inherent advantages and disadvantages (Table 1). Although the questionnaires assess the impact of a reported voice problem, there are some particularities that make them complementary and not totally interchangeable.16,17 When the time of administration is taken into account, the QVV is the fastest to complete, if the point is to map areas that suffer from greater impact of a voice problem, the PPAV is the only one that offers such information; on the other hand, if the purpose is to assess the handicap a dysphonic individual present with, the IDV provides a better overview.

The first instrument validated was the QVV. This selection was based on its fuctionality and clearness of its 10 items, of which 6 are from the physical domain and 4 from the social-emotional. The items are straight forward and the average time for filling in is three minutes. The questionnaire provides a total and each domain scores. Although it was not difficult to traslate the statements of the questionnaire, changes on the sentences of the rating scale were necessary, since they were originally based on the degree and frequency of the vocal deviation. This double attribute made the Brazilian respondents confuse and so, the original format had to be changed.

In order to evaluate cultural and linguistic equivalency of the QVV, the option "not applicable" was introduced to each item of the questionnaire and was administered to 38 patients. None of the questions showed to be invalid. The instrument was administered to 234 individuals, 114 presenting with vocal complaint, 19 men and 95 women, aged between 18 to 79 years, mean of 41,3 years and to 120 individuals presenting with dermatological complaints, 31 men and 89 women, aged between 16 to 75 years, mean of 43 years. All individuals also gave a self-rating of his/her voice quality using a Likert Scale with 5 items: poor, fair, good, very good, or excellent. 19 patients submitted to voice rehabilitation were administered a post-treatment V-RQOL questionnaire and also gave a post-treatment selfrating of voice quality. The validation was determined by the comparison of the dysphonic and non-dysphonic group, with statistical differences, considering the self-assessment of vocal quality and different domains of the instruments (Table 2; vocal complaint group: total score $-\mathrm{p}=0.008$, physical score $\mathrm{p}=0.007$ and socioemotional score $\mathrm{p}=0.03$; dermatological complaint group: total score $-\mathrm{p}=0.091$, physical score $\mathrm{p}=0.168$ and socioemotional score $\mathrm{p}=0.67$ ). Results showed that internal consistency was demonstrated with high coefficient values (Table $2 ; \mathrm{p}<0,001)$ and a statistically acceptable level of reliability (Table 3; functioning 0,700 ; socialemotional 0,070 e total 0,108 ). Pre and posttreatment results showed a significant responsiveness.

The second protocol validated to Brazilian Portuguese was the VAPP that is a 28 -item assessment tool that evaluates the perception of a voice problem, activity limitation, and participation restriction based on the ICF concept of WHO. It consists of five sections: self-perceived severity of voice problem (1 item), effect on job (4 items), effect on daily communication (12 items), effect on social communication (4 items) and effect on emotion ( 7 items). The statements are simple and the average time of administration is eight minutes. The instrument uses a visual analog scale with a length of $10 \mathrm{~cm}$ indicating "never" in one extreme and "always" at the other; therefore, the maximum value for a question is 10 and for the total questionnaire 280, reflecting a maximum negative impact of voice impairment of activities and participation. There was no need to include a Likert scale with five points for the self-assessment of vocal quality since the first question of this questionnaire is correspondent to this analysis. This instrument allows the calculation of two other scores: activity limitation and participation restriction. The assessment of these to domains help to understand whether the voice problem produces changes in the way individuals participate in activities, such aspect showed to be equally interesting for the Brazilian subjects when compared to the original version. 12 The instrument was administered to 50 people, 25 with vocal complaint, 14 women, 11 men, mean age 37 years; and 25 without vocal complaint (with dermatological complaints), 18 women, 7 men, mean age $37 \mathrm{old}$. For cultural adaptation, the protocol was administered to 10 patients. None of the questions showed to be invalid. The questionnaire was applied twice to 25 patients with vocal complaint, to determine reliability and testretest reproducibility. Six patients underwent voice therapy to determine responsiveness to treatment. Validation was determined by the comparison of the dysphonic and non-dysphonic 
group and the different aspects, with statistical differences, (Table 2; job p=0,002, daily communication $\mathrm{p}=0,017$, social communication $\mathrm{p}<0,001$, emotion $\mathrm{p}<0,001)$ of the instrument. Internal consistency of the questionnaire was determined with high values of Alpha coefficient (Table 2; $<<0,001$ ). Results showed an acceptable level of reproducibility (Table 3 ; job $p=0,246$, daily communication $\mathrm{p}=0,345$, social communication $\mathrm{p}=0,618$, emotion $\mathrm{p}=0,367$; total $\mathrm{p}=0,545)$. Responsiveness to treatment (Table 3) was determined by significant changes between results pre and post-treatment for Total score $(\mathrm{p}=0,046)$, daily communication $(\mathrm{p}=0,046)$ and emotion $(\mathrm{p}=0,046)$, however, it is likely that there was no significance in the job aspects $(\mathrm{p}=0,116)$ and social communication $(\mathrm{p}=0,249)$ due to the small number of subjects submitted to treatment.

Finally, the latest one validated in Brazil was the IDV that was considered the considered the most challenging protocol because of the similarities between some items, such as items F1 and F2 (F1. My voice makes it difficult for people to hear me; F2. People have difficulty understanding me in a noisy room) and items P5 and P8 (P5. I feel as though I have to strain to produce voice; P8. I use a great deal of effort to speak). The statements are simple however the similarities among them make the respondents think and the average time of administration is 10 minutes. Scores may vary from 0 to 120 , with the latter representing the maximum perceived disability due to voice difficulties, according to individuals' response. This questionnaire was already validated into another language: Taiwan18, British English19, French, Polish21, German22, Dutch23, Chinese24, Hebrew25, Espanish26, Italian, Flemish-dutch, Portuguese from Portugal and Swedish.27 Psychometric measure of validity, reproducibility, internal consistency and reliability were demonstrated for all of them with similar and comparable results obtained for the Brazilian population.
IDV was administered to 116 individuals, 52 presenting with vocal complaint, 14 men and 38 women, aged between 18 to 79 years, mean of 42.3 years and to 64 individuals with no vocal complaints (with ophthalmologic complaints), 20 men and 44 women, aged between 18 to 76 years, mean of 41.1 years. All individuals gave a selfrating of his/her voice quality using a Likert Scale with 5 items: "excellent to poor".For cultural adaptation, the instrument was also administered to 10 patients. None of the questions showed to be invalid. Ten other subjects with vocal problems were also submitted to voice rehabilitation for testing responsiveness. To determine test-retest reproducibility, 52 voice patients were administered the IDV a second time. The validation was determined by comparing the groups, with statistical differences, considering the selfassessment of vocal quality and different domains of the instrument (Table $2 p<0.001$ for all groups and domains). Results showed that internal consistency was demonstrated with high coefficient values (Table $2 ; \mathrm{p}<0,001$ ) and a statistically acceptable level of reliability (Table 3 ; functional 0.400 ; emotional 0.630 , organic 0.310 and total 0,100$)$. Pre and post-treatment results showed a significant responsiveness (Table 3; $\mathrm{p}$ $=0.05$ for all domains). Therefore, results from validations into other languages are comparable to the data obtained for the Brazilian individuals.

\section{Conclusion}

The QVV, PPAV and IDV are instruments that specifically assess patients presenting with voice problems. They are valid, reliable and responsive to change for the Brazilian population. The Brazilian versions can be proposed as useful tools to evaluate different aspects of quality of life of dysphonic patients and treatment outcomes. The experience of going through all steps helped us to understand the commonality among patients with voice disorders and some similarities that brighten the world diversity. 


\section{References}

1. World Health Organization. Measuring Quality of Life The World Health Organization Quality of Life Instruments. WHO/MSA/MNH/PSF. 1997;1-15.

2. Guyatt GH, Feeny DH, Patrick DL. Measuring healthrelated quality of life. Ann Intern Med. 1993;118:622-9.

3. Gill TM, Feinstein AR. A Critical Appraisal of the quality of Quality-of-life Measurements. JAMA. 1994;272:61926.

4. Guillemin F, Bombardier C, Beaton D. Cross-cultural adaptation of health-related quality of life measures: literature review and proposed guidelines. J Clin Epidemiol. 1993;46:1417-32.

5. Ciconelli RM, Ferraz MB, Santos W, Meinão I, Quaresma MR. Tradução para a língua portuguesa do questionário genérico de qualidade de vida SF-36 (Brasil SF-36). Ver Bras Reumatol. 1999;39:143-50.

6. Behlau M, Pontes P. Avaliação e tratamento das disfonias. São Paulo: Lovise; 1995.

7. Hartnick CJ. Validation of a Pediatric Voice Quality-oflife Instrument: The Pediatric Voice Outcome Survey. Arch Otolaryngol Head Neck Sur. 2002;128:919-22.

8. Scientific Advisory Committee of Medical Outcomes Trust. Assessing health status and quality of life instruments: Attributes and review criteria. Qual Life Res. 2002;11:193205.

9. Hogikyan ND, Sethuraman G. Validation of an instrument to measure voice-related quality of life (V-RQOL). J Voice. 1999;13:557-69.

10. Gasparini G, Behlau M. Validação do questionário de avaliação de qualidade de vida em voz - QVV. Anais do XIV Congresso Brasileiro de Fonoaudiologia; 2006.

11. Gasparini G, Behlau M. Quality of Life: validation of the Brazilian version of the Voice-Related Quality of Life Measure (V-RQOL). J Voice, 2007, in print.

12. Ma EP-M, Yiu EM-L. Voice activity and participation profile: Assessing the impact of voice disorders on daily activities. J Speech Hear Res. 2001;44:511-24.

13. Ricarte A, Gasparini G, Behlau M. Validação do Protocolo Perfil de Participação e Atividades Vocais (PPAV) no Brasil. Anais do XIV Congresso Brasileiro de Fonoaudiologia; 2006.

14. Jacobson HB, Johnson A, Grywalski C, Sillbergleit AK, Jacobson GP, Benninger M, Newman CW. The voice Handicap Index (VHI): development and validation. Amer J Speech Lang Pathol. 1997;6:66-70.

15. Behlau M, Santos LMA, Oliveira G. Cross-cultural adaptation and validation of the voice handicap index into brazilian portuguese. J Voice 2009 /in press/.
16. Franic DM, Bramlett RE, Bothe AC. Psychometric evaluation of disease specific quality of life instrumente in voice disorders. J Voice. 2005;19:300-15.

17. Portone CR, Hapner ER, McGregor L, Otto K, Johns III MM. Correlation of the Voice Handicap Index (VHI) and the Voice-related Quality of Life Measure (V-RQOL). J Voice. 2007;21:723-7.

18. Hsiung MW, Lu P, Kang BH, Wang HW. Measurement and validation of the voice handicap index in voicedisordered patients in Taiwan. J Laryngol Otol, 2003 Jun 117(6):478-81.

19. Deary IJ, Webb A, Mackenzie K, Wilson JA, Carding PN. Short, self-report voice symptom scales: psychometric characteristics of the voice handicap index-10 and the vocal performance questionnaire. 2004 Sep 131(3):232-5.

20. Woisard V, Bodin S, Puech M. The Voice Handicap Index: impact of the translation in French on the validation. Rev Laryngol Otol Rhinol (Bord). 2004;125(5):307-12.

21. Pruszewicz A, Obrebowski A, Wiskirska-Woznica B, Wojnowski W. Complex voice- assessmente-Polish version of the Voice Handicap Index (VHI). Otolaryngol Pol. 2004;58(3):547-9.

22. Günther S, Rasch T, Klotz M, Hoppe U, Eysholdt U, Rosanowski F. Determination of subjective impairment in dysphonia. A methodological comparison. HNO, 2005 Oct 53(10):895-900,902-4.

23. Hakkesteegt MM, Wieringa MH, Gerritsma EJ, Feenstra L. Reproducibility of the Dutch version of the Voice Handicap Index. Folia Phoniatr Logop. 2006;58(2):1328 .

24. Lam PK, Chan KM, Ho WK, Kwong E, Yiu EM, Wei WI. Cross-cultural adaptation and validation of the Chinese Voice Handicap Index-10. Laryngoscope. $2006 \mathrm{Jul}$ 116(7):1192-8.

25. Amir O, Tavor Y, Leibovitzh T, Ashkenazi O, Michael O, Primov-Fever A, Wolf M. Evaluating the validity of the Voice Handicap Index-10 (VHI-10) among Hebrew speakers. Otolaryngol Head Neck Surg. 2006 Oct 135(4):603-7.

26. Núñez-Batalla F, Corte-Santos $\mathrm{P}$, Señaris-González B, Llorente-Pendás JL, Górriz-Gil C, Suárez-Nieto C. Adaptation and validation to the Spanish of the Voice Handicap Index (VHI-30) and its shortened version (VHI10) Acta Otorrinolaringol Esp. 2007 Nov 58(9):386-92.

27. Verdonck-de Leeuw IM, Kuik DJ, De Bodt M, Guimaraes I, Holmberg EB, Nawka T, Rosen CA, Schindler A, Whurr $\mathrm{R}$, Woisard V Validation of the Voice Handicap Index by Assessing Equivalence of European Translations. Folia Phoniatr Logop. 2008 Apr 24;60(4):173-8. 